\title{
Phytochemical and Pharmacological Evaluation of Selected Plants
}

\author{
Sneh Verma, Tandra Mohanta, \\ T. Revathy, K. Suthindhiran and M.A. Jayasri \\ School of Bioscience and Technology, \\ Vellore Institute of Technology University, Tamil Nadu, India
}

Received 2012-05-31, Revised 2013-07-10; Accepted 2013-07-26

\begin{abstract}
Araucaria cookii, Bauhinia blakeana and Brassaia actinophylla are ornamental plants. The presence of various phytochemicals and pharmacologically important compounds in these plants can be exploited for their medicinal use. But there are no reports on the phytochemical and pharmacological evaluation of these plants and this study aims at investigating these. The plant extracts were prepared in different solvents like methanol, ethanol, ethyl acetate, acetone, hexane, water and chloroform. Qualitative analysis of phytochemicals were assessed. The anti-microbial, anti-oxidant and enzyme inhibitory activity was determined for all three plant extracts. Anti-bacterial activity against three gram negative bacteria, E. coli, Pseudomonas and Klebsiella was done and Araucaria cooki showed highest antibacterial activity among the three plants. Maximum antioxidant activity was seen in methanol extract of Brassaia actinophyla with $81 \%$ inhibition. The order of the antioxidant activity of the three plants are in the order B.actinophylla $>A$ cookie $>$ B.blakeana. The results of phytochemical analysis suggest that phytosteroids are present in all the three plants. Maximum inhibition against the tested enzymes was exhibited by hexane and chloroform extracts of A.cookii. Hemolytic activity was done and the hexane extract showed maximum haemolysis where as aqueous extracts showed minimum activity. From the results it is clear that the three plant extracts has pharmacological applications. This is the first report of antimicrobial, antioxidant and enzyme inhibitory activities of these three plant extracts. Further studies are needed to exploit the actual mechanism and active compounds of these plants.
\end{abstract}

Keywords: Araucaria Cookii, Bauhinia Blakeana, Brassaia Actinophylla, Antioxidant, Phytochemical

\section{INTRODUCTION}

Medicinal plants are the primary source of medicine for the treatment of human diseases in many rural areas of the developing countries (Chitme et al., 2004). About $80 \%$ of the world population relies on the traditional medicine for their primaryhealth care (Owolabi and Omogbai, 2007). The medicinal value of the plant is due to the presence of various bioactive chemical constituents such as alkaloids, tannins, flavanoids and phenolic compounds (Hill, 1952) Therefore, the plants with the medicinal values have to be investigated to understand their safety and efficacy (Nascimento et al., 2000).

The main cause for diseases and ageing is due to the oxidative damage to the cell. Oxidative stress occurs due to the imbalance in the oxidants and antioxidants, resulting in the oxidative damage to the molecules. Free radicals attack lipids and DNA by inducing oxidations that cause membrane damage leading to cancer (Pietta, 2000; Cerutti, 1994). A potent free radical scavenger may serve as intervention for free radical mediated diseases (Ames et al., 1995). Recent reports showed Tamil Nadu, India Tel: 9944024206 
that plant products including polyphenolic compounds (e.g., flavanoids and tannins) and various plant extracts exhibit antioxidant activities (Iqbal et al., 2009; Kiselova et al., 2006).

Multiple drug resistance has been developed due to the use of commercial antibiotics in the treatment of infectious diseases. Therefore scientists have started looking for new antibiotics. There is a need to develop antimicrobials for the treatment of diseases from medicinal plants (Agrawal et al., 1996). The general antimicrobial activities of medicinal plants and plant products, such as essential oils, have been reviewed previously (Cowan, 1999; Kalemba and Kunika, 2003). The plant extracts and their phytochemicals having antimicrobial (antibacterial) properties plays an important role in the therapeutic treatments. The most important constituents of plants are alkaloids, tannins, flavonoids and phenolic compounds (Hill, 1952). The medicinal values of the selected plants depend upon the physiological action and their effects on human body (Edeoga et al., 2005).

Plants have long been used for the treatment of diabetes and the research on medicinal plants for the management of diabetes has attracted the interest of scientists (Ali et al., 2006; McCue et al., 2005). Alpha amylase and alpha glucosidase inhibitors are reported to be present in plant extracts (Ingrid and Matthias, 2006). Inhibition of these two enzymes helps in the management of type II diabetes mellitus.

Brassaia actinophylla belongs to Araliaceae family, widely distributed in tropical rainforests in Australia and New Guinea. It is grown as decorative trees in the gardens. Bauhinia blakaena is an evergreen tree with large thick leaves and striking purplish red flowers, sometimes called as 'Hong Kong Orchid'. It is sterile and hybrid between Bauhinia variegate and Bauhinia pupurea. Propagation is by cutting and air layering. There is no data found before about its biological activities. Araucaria cookii is a tall tree, used as a decorative plant, commonly called as Christmas tree. In our study we have evaluated the various photochemical and pharmacological applications of Araucaria cookii, Bauhinia blakeana and Brassaia actinophylla.

\section{MATERIALS AND METHODS}

\subsection{Plant Material and Extraction}

Leaves of Araucaria cookii, Bauhinia blakeana and Brassaia actinophylla were collected from horticulture nursery of VIT University, Vellore. The leaves were shade dried, crushed, powdered and extracted (100 g $\mathrm{mL}^{-1}$ ). Methanol, ethanol, hexane, chloroform, distilled water, acetone and ethyl acetate were the various solvents used for extraction. It was then kept undisturbed in orbital shaker for 5 days at room temperature. The supernatant was collected and utilised for the assessment of the various activities.

\subsection{Qualitative Analysis of Phytochemicals}

The Following screening tests were carried for the various extracts of the three plants to detect the presence of phytochemicals.

\subsection{Detection of Saponins (Kokate, 1999)}

About $0.5 \mathrm{~mL}$ of extract was dissolved in $5 \mathrm{~mL}$ of distilled water in a test tube. Persistent frothing on warming indicates the presence of saponins. The ability of saponins to produce frothing in aqueous solution was used as a screening test for the sample.

\subsection{Detection of Tannins (Trease and Evans, 1996)}

About $0.5 \mathrm{~mL}$ of extract was dissolved in $5 \mathrm{~mL}$ of distilled water. To it, a few of neutral ferric chloride solution was added. Formation of blue precipitate indicates the presence of tannins.

\subsection{Detection of Phenols (Mace, 1963)}

About $0.5 \mathrm{~mL}$ of extract was dissolved in $5 \mathrm{~mL}$ of distilled water. To it, a few drops of neutral 5\% ferric chloride was added. A dark green colour indicates the presence of phenols.

\subsection{Detection of Flavonoids (Evans, 1997)}

About $0.5 \mathrm{~mL}$ of extract was treated with $5 \mathrm{~mL}$ of $10 \%$ ammonium hydroxide solution. A yellow fluorescence indicated the presence of flavonoids.

\subsection{Detection of Phytosteroids (Finer, 1988)}

About $50 \mu \mathrm{L}$ of extract was treated with $2 \mathrm{~mL}$ of acetic anhydride. To it, 1-2 drops of conc. sulphuric acid was added along sides of the test tube. An array of colour showed presence of phytosteroids.

\subsection{Evaluation of Antioxidant Activity Using DPPH Model}

The radical scavenging activity was determined using DPPH which was described by Menser et al. (2001). $2 \mathrm{~mL}$ of $0.3 \mathrm{mM}$ alcoholic solution of DPPH was added to $2 \mathrm{~mL}$ of the samples extracted with 
solvents like methanol, ethanol, water, ethyl acetate, hexane, chloroform, acetone. The samples were kept in the dark for $30 \mathrm{~min}$ after which the optical density was measured at $518 \mathrm{~nm}$. The radical scavenging activity was determined by the following formula:

$$
\mathrm{AA} \%=\left(\mathrm{A}_{\text {control }}-\mathrm{A}_{\text {sample }}\right) / \mathrm{A}_{\text {control }} * 100
$$

where, $\mathrm{A}_{\text {control }}$ is the absorbance of free radical alone and $\mathrm{A}_{\text {sample }}$ is the absorbance of the free radical in the presence of extract. The optical density of samples was measured against methanol which was taken as blank.

\subsection{Evaluation of $\alpha$-Amylase and $\alpha$-Glucosidase Inhibitory Activity \\ 2.9.1. Inhibition Assay for Porcine a-Amylase Activity}

About $500 \mu \mathrm{L}$ of extract was taken and mixed with $500 \mu \mathrm{L}$ of $0.02 \mathrm{M}$ sodium phosphate buffer ( $\mathrm{pH} 6.9$ with $0.006 \mathrm{M}$ sodium chloride) containing $\alpha$-amylase solution $\left(0.5 \mathrm{mg} \mathrm{mL}{ }^{-1}\right)$ and incubated for $10 \mathrm{~min}$ at $25^{\circ} \mathrm{C}$. After incubation, $500 \mu \mathrm{L}$ of $1 \%$ starch solution in $0.02 \mathrm{M}$ sodium phosphate buffer was added to each tube at $5 \mathrm{~s}$ intervals. The reaction mixture was incubated at $25^{\circ} \mathrm{C}$ for $10 \mathrm{~min}$ and finally the reaction was stopped with $1.0 \mathrm{~mL}$ of dinitrosalicylic acid color reagent. The test tubes were then incubated in boiling water bath for $5 \mathrm{~min}$ and cooled to room temperature. The reaction mixture was then diluted by adding $10 \mathrm{~mL}$ distilled water and absorbance was measured at $540 \mathrm{~nm}$. Percentage of inhibition was calculated by this formula:

$$
\% \text { inhibition }=\left[\mathrm{A}_{540 \text { control }}-\mathrm{A}_{540 \text { extract }}\right] \mathrm{X} 100 / \mathrm{A}_{540 \text { control }}
$$

\subsection{Inhibition Assay for Yeast a- Glucosidase Activity}

About $50 \mu \mathrm{L}$ of extract was mixed with $100 \mu \mathrm{L}$ of $0.1 \mathrm{M}$ phosphate buffer containing $\alpha$-glucosidase solution and incubated in 96 wells plate at $25^{\circ} \mathrm{C}$ for $10 \mathrm{~min}$. After incubation, $50 \mu \mathrm{L}$ of $5 \mathrm{mM}$ p-nitro phenyl a-D-glucopyranoside solution in $0.1 \mathrm{M}$ phosphate buffer was added to each well at $5 \mathrm{~s}$ intervals. The reaction mixture was incubated at $25^{\circ} \mathrm{C}$ for $5 \mathrm{~min}$. After incubation, absorbance was recorded at $540 \mathrm{~nm}$ by micro-array reader and compared with control which had $50 \mu \mathrm{L}$ of buffer solution in place of extract. The inhibitory activity was calculated by this formula:

$$
\text { \%inhibition }=\left[\left(\mathrm{A}_{\text {control540 }}-\mathrm{A}_{\text {extract540 }}\right)\right] * 100 / \mathrm{A}_{\text {control } 540}
$$

\subsection{Determination of Antibacterial Activity}

E.coli, Pseudomonas and Klebsiella are the test bacterial cultures used. The bacterial cultures were swabbed on to Muller Hinton agar media. A total of $6 \mathrm{~mm}$ diameter wells were punched into agar and filled with plant extracts (distilled water, hexane, methanol, ethanol, ethyl acetate, chloroform and acetone). The bacterial plates were then incubated at $37^{\circ} \mathrm{C}$ for $48 \mathrm{~h}$. The antibacterial activity was evaluated by measuring the zone of inhibition.

\subsection{Evaluation of Hemolytic Activity}

Human blood was obtained from of a healthy volunteer. Collected blood was washed 3 times in nine volumes of sterile $0.9 \% \mathrm{Nacl}$ saline solution. After each washing, cells were centrifuged at $1000 \mathrm{rpm}$ for $5 \mathrm{~min}$ and the supernatant was discarded. The final pellet was diluted $1 / 9(\mathrm{~V} / \mathrm{V})$ in sterile $0.9 \% \mathrm{Nacl}$ saline solution then $1 / 24(\mathrm{~V} / \mathrm{V})$ in sterile Dulbecco's Phosphate Buffer (D-PBS). The hemolytic activity of crude extract was tested by Malogoli's method under invitro condition in 96 well plate. $100 \mu \mathrm{L}$ of $0.85 \%$ Nacl solution containing $10 \mathrm{mM} \mathrm{Cacl} 2$ was added to each well. The first well served as negative control and contained PBS buffer and the second well onwards contained $100 \mu \mathrm{L}$ of sample extracts. The last well served as positive control containing $100 \mu \mathrm{L}$ of $0.1 \%$ triton $\mathrm{X}-100$ in $0.85 \%$ saline. Then $100 \mu \mathrm{L}$ of $2 \%$ suspension of human erythrocytes in $0.85 \%$ saline containing $10 \mathrm{mM} \mathrm{Cacl}_{2}$ was added to each well and incubated for $30 \mathrm{~min}$ at room temperature. It was then centrifuged and supernatant was used to measure the absorbance of the liberatedhaemoglobin at $540 \mathrm{~nm}$. The average value was calculated from triplicate assay.

\section{RESULTS}

\subsection{Phytochemical Analysis}

The presence of different phytochemicals in the plant extracts are summarised in the Table 1-3. Saponin was detected in Brassaia actinophyla (methanol and aqueous extracts), Bauhinia blakaena (Methanol extract) and Araucaria cookii (methanol and ethyl acetate). Tanins were found in many extracts including ethyl acetate and aqueous extracts of Brassaia actinophyla, water, methanol, ethyl acetateand chloroform extracts of Bauhinia blakaena and methanol, acetone and ethanol extracts of Araucaria cookii. 
Table 1. Qualitative analysis of B.actinophylla for the presence of phytochemicals

\begin{tabular}{llllll}
\hline Extracts & Saponins & Tannins & Phenols & Flavonoids & Phytosteroids \\
\hline Methanol & + & - & + & - & + \\
Ethanol & - & - & + & - & + \\
Ethyl acetate & - & + & - & - & + \\
Chloroform & - & - & + & - & + \\
Hexane & - & - & + & - & + \\
Water & + & + & + & - & + \\
Acetone & - & - & & & + \\
\hline
\end{tabular}

Table 2. Qualitative analysis of B.blakeana for the presence of phytochemicals

\begin{tabular}{llllll}
\hline & Saponins & Tannins & Phenols & Flavonoids & Phytosteroids \\
\hline Methanol & + & + & - & + & + \\
Ethanol & - & - & + & - & + \\
Ethyl acetate & - & + & - & - & + \\
Chloroform & - & + & - & - & + \\
Hexane & - & - & + & + & + \\
Water & - & + & + & + & + \\
Acetone & - & - & + & & + \\
\hline
\end{tabular}

Table 3. Qualitative analysis of A.cookii for the presence of phytochemicals

\begin{tabular}{llllll}
\hline Extracts & Saponins & Tannins & Phenols & Flavonoids & Phytosteroids \\
\hline Methanol & + & + & - & + & + \\
Ethanol & - & + & - & - & + \\
Ethyl acetate & + & - & + & - & + \\
Chloroform & - & - & + & - & + \\
Hexane & - & - & + & + & + \\
Water & - & - & - & + & + \\
Acetone & - & + & & & + \\
\hline
\end{tabular}

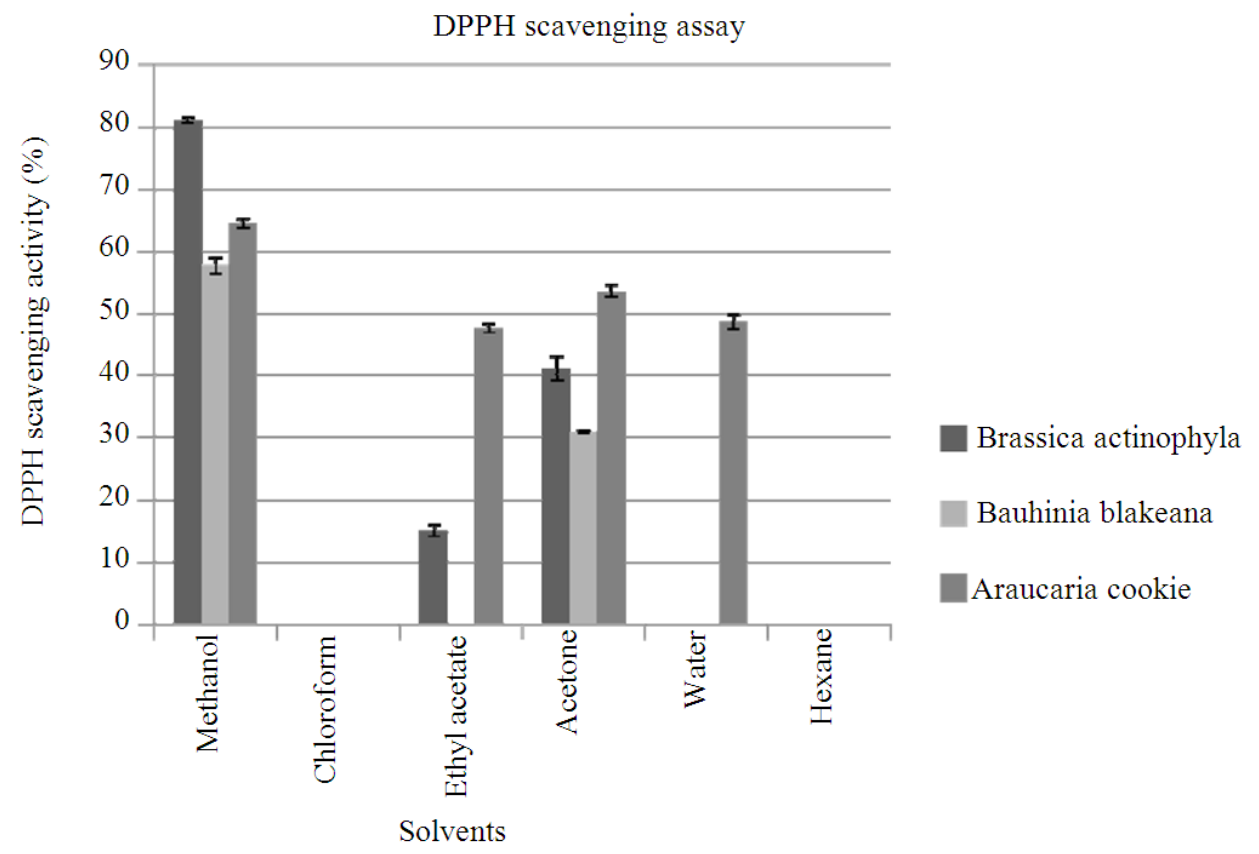

Fig. 1. DPPH Scavenging assay of the three plant extracts. Methanolic extract of Brassica actinophyla with maximum activity followed by Araucaria cookii and Bauhinia blakeana 


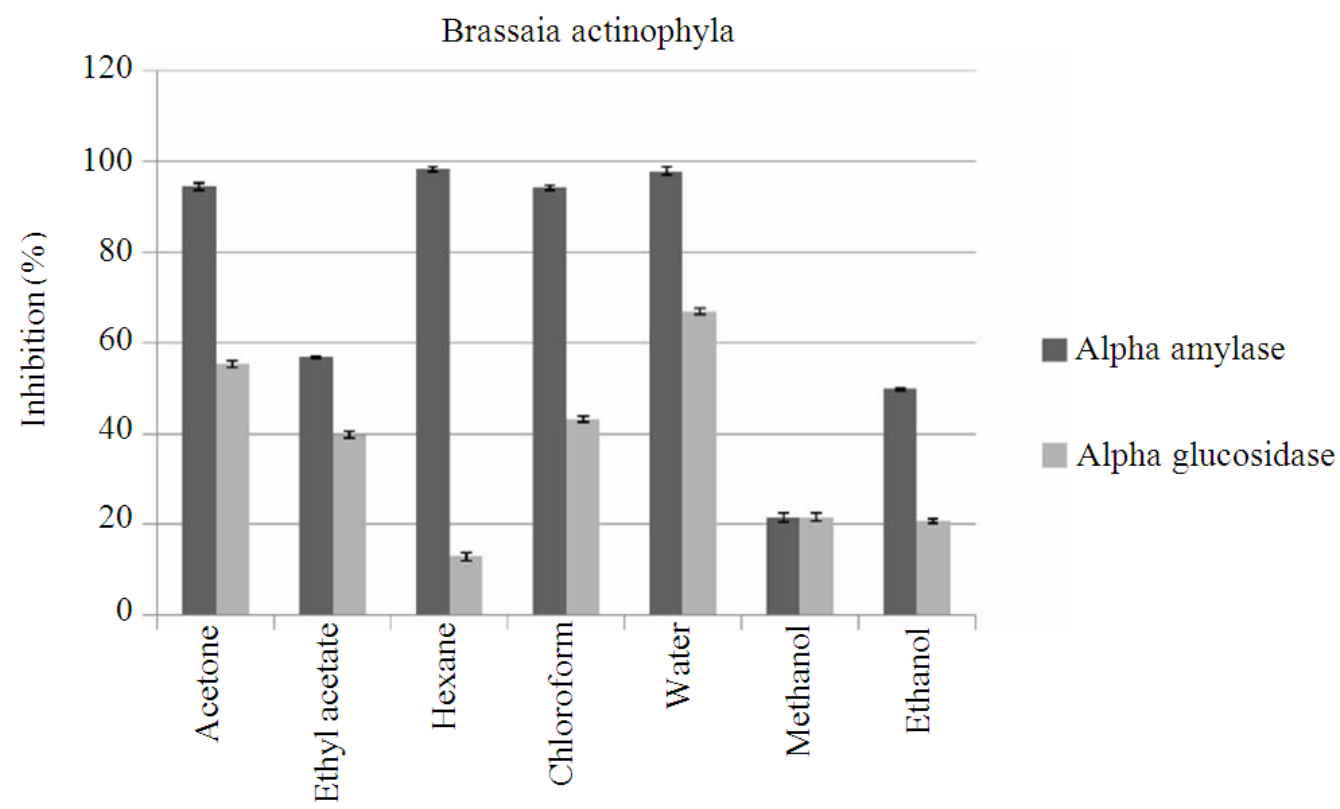

Solvents

Fig. 2. Alpha amylase and alpha glucosidase inhibition by Brassaia actinophyla

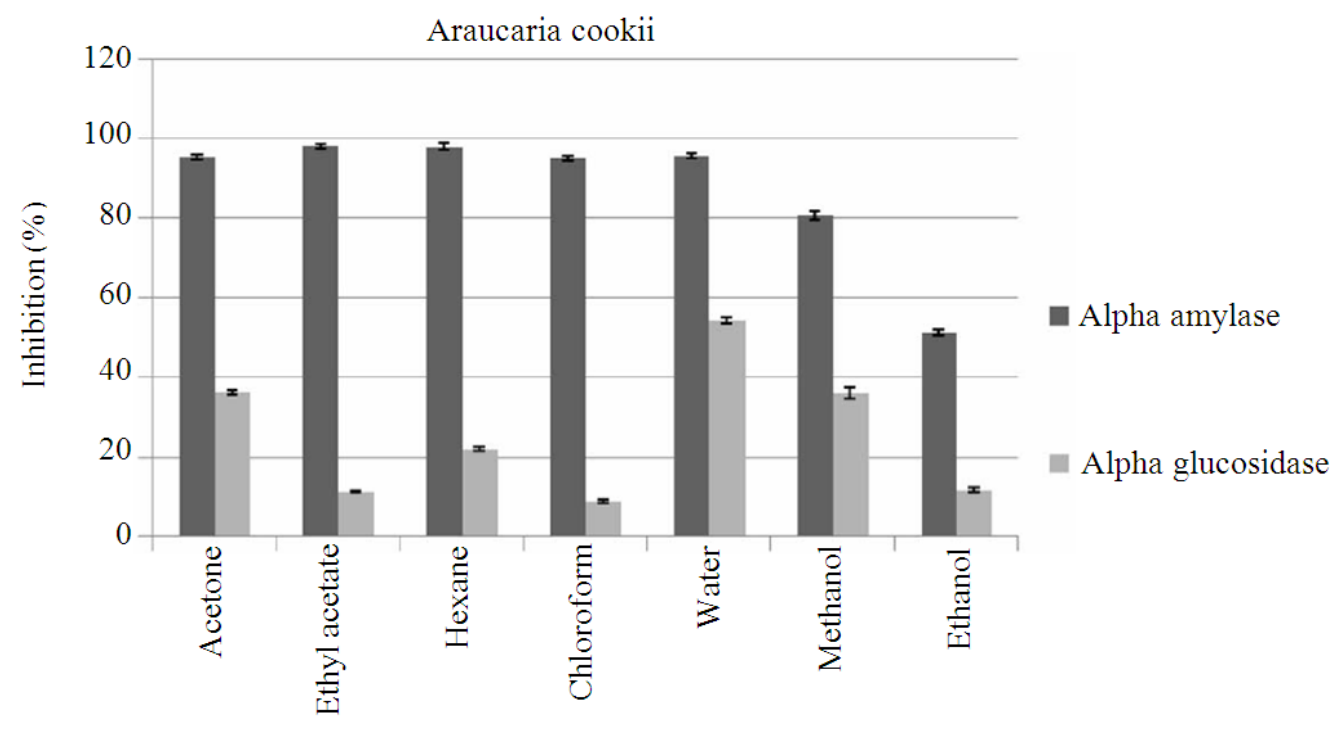

Solvents

Fig. 3. Alpha amylase and alpha glucosidase inhibition by Araucaria cookie

Flavonoids were not found in Brassaia actinophyla and was detected in water, methanol and acetone extracts of Bauhinia blakaena and in methanol and acetone extracts of Araucaria cookii. Phytosteroids was detected in all the extracts of the three plants taken under study.

\subsection{DPPH Radical Scavenging Activity}

The antioxidant activity of the three plant extracts is given in the Fig. 1. The antioxidant activity was found to be maximum in methanol extract of B.actinophylla having the highest value of $81 \%$ than the other two. 


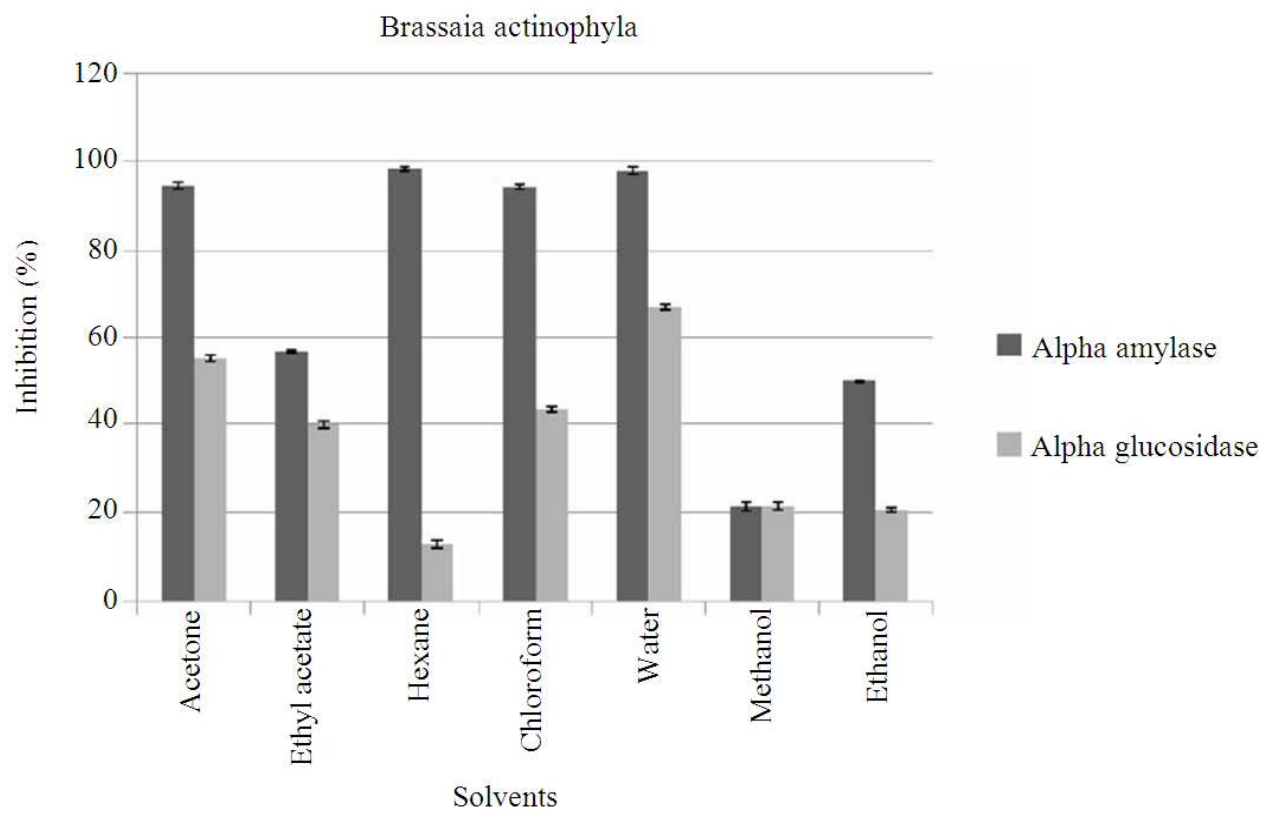

Fig. 4. Alpha amylase and alpha glucosidase inhibition by Bauhinia blakeana

Table 4. Antibacterial activity of three plant extracts against Pseudomonas

\begin{tabular}{llll}
\hline Extracts & A.cookii & B.actinophylla & B.blakeana \\
\hline Ethanol & $\mathrm{R}$ & $\mathrm{R}$ & $\mathrm{R}$ \\
Methanol & $\mathrm{R}$ & $\mathrm{R}$ & $\mathrm{R}$ \\
Ethyl acetate & $\mathrm{R}$ & $\mathrm{R}$ & $\mathrm{R}$ \\
Hexane & $\mathrm{R}$ & $\mathrm{R}$ & $\mathrm{R}$ \\
Chloroform & $2 \mathrm{~mm}$ & $\mathrm{R}$ & $\mathrm{R}$ \\
Water & $\mathrm{R}$ & $\mathrm{R}$ & $\mathrm{R}$ \\
Acetone & $5 \mathrm{~mm}$ & $\mathrm{R}$ & $\mathrm{R}$ \\
\hline
\end{tabular}

Table 5. Anti bacterial activity against E.coli

\begin{tabular}{llll}
\hline Extracts & A.cookii & B.actinophylla & B.blakeana \\
\hline Ethanol & $\mathrm{R}$ & $\mathrm{R}$ & $\mathrm{R}$ \\
Methanol & $\mathrm{R}$ & $\mathrm{R}$ & $\mathrm{R}$ \\
Ethyl acetate & $\mathrm{R}$ & $\mathrm{R}$ & $\mathrm{R}$ \\
Hexane & $\mathrm{R}$ & $\mathrm{R}$ & $\mathrm{R}$ \\
Chloroform & $\mathrm{R}$ & $\mathrm{R}$ & $\mathrm{R}$ \\
Water & $\mathrm{R}$ & $\mathrm{R}$ & $\mathrm{R}$ \\
Acetone & $\mathrm{R}$ & $\mathrm{R}$ & $\mathrm{R}$ \\
\hline
\end{tabular}

Table 6. Anti bacterial activity against Klebsiella $s p$

\begin{tabular}{llll}
\hline Extracts & A.cookii & B.actinophylla & B.blakeana \\
\hline Ethanol & $\mathrm{R}$ & $\mathrm{R}$ & $\mathrm{R}$ \\
Methanol & $\mathrm{R}$ & $\mathrm{R}$ & $\mathrm{R}$ \\
Ethyl acetate & $\mathrm{R}$ & $\mathrm{R}$ & $\mathrm{R}$ \\
Hexane & $\mathrm{R}$ & $\mathrm{R}$ & $\mathrm{R}$ \\
Chloroform & $\mathrm{R}$ & $\mathrm{R}$ & $\mathrm{R}$ \\
Water & $\mathrm{R}$ & $\mathrm{R}$ & $\mathrm{R}$ \\
Acetone & $\mathrm{R}$ & $\mathrm{R}$ & $\mathrm{R}$ \\
\hline
\end{tabular}

Similarly, hexane extract of all the three plants possessed the least antioxidant activity. Some However, the order of antioxidant activity of the three plants are in the order B.actinophylla $>$ A cookie $>$ B.blakeana.

\section{3. $\alpha$-Amylase and $\alpha$-Glucosidase Inhibition}

From the results obtained, it was observed that the various extracts of the three plants exhibited greater $\alpha$ amylase inhibitory activity compared to $\alpha$-glucosidase activity. The results of $\alpha$-amylase and $\alpha$-glucosidase inhibition is given in the Fig. 2-4. Hexane and chloroform extracts exhibited highest $\alpha$-amylase inhibitory activity while methanol and ethanol extract exhibited the least inhibitory activity in all the three plants. Similarly, aqueous extract exhibited highest $\alpha$ glucosidase inhibitory activity in all the three plants. Extracts of A.cookii showed highest variations in $\alpha$ amylase and $\alpha$-glucosidase inhibitory activity while the other two B.actinophylla and B.blakeana showed moderate variations in their activities.

\subsection{Antibacterial Activity}

The antibacterial activity of the three plant extracts is given in the Table 4-7. Acetone extract of Araucaria cookii was found to be the most potent antibacterial agent in comparison to other extracts. Chloroform extract of Araucaria cookii showed similar antibacterial activity but less significant in comparison to acetone extract. 
Table 7. $\mathrm{EC}_{50}$ values of different plant extracts

\begin{tabular}{llllllll}
\hline Extracts & Methanol & Ethanol & Water & Chloroform & Hexane & $\begin{array}{l}\text { Ethyl } \\
\text { acetate }\end{array}$ & Acetone \\
\hline B.actinophylla & 111.0 & 107.07 & 26.94 & 42.93 & 122.56 & 108.42 & 83.00 \\
B.blakeana & 145.0 & 66.160 & 16.33 & 67.51 & 109.60 & 138.38 & 123.91 \\
A.cookii & 30.80 & 126.94 & 38.22 & 87.21 & 118.52 & 92.590 & 54.710 \\
\hline
\end{tabular}

$\mathrm{EC}_{50}$ value- amount of extract $\left(\mu \mathrm{g} \mathrm{mL}^{-1}\right)$ required to lyse $50 \%$ of erythrocytes

The acetone and chloroform extract of Araucaria cooki inhibited Pseudomonas.

\subsection{Hemolytic Activity Assay}

The different extracts of the plants induced pronounced hemolysis on human blood which is summarised in Hexane extract of all the three plants showed the maximum hemolytic activity while the aqueous extract exhibited the minimum hemolytic activity.

\section{DISCUSSION}

Araucaria cookii, Bauhinia blakeana, Brassaia actinophylla are non medicinal plants and are used for ornamental purposes. In our study we are first time reporting the presence of tannins, flavonoids and saponins in these three plants. Tannins act as antioxidants (Halliwell and Gutteridge, 1989). From Our results it is clear that tannins are present in the three plant extracts and they can be used as astringents. Tannins also have antibacterial (Akiyama et al., 2001) activity. Saponins are diverse family of secondary metabolites with many medicinal values, which has antimicrobial activity (Osbourn, 2003) and extremely toxic to cold-blooded animals, but toxicity to mammals is low (Dini et al., 2001).

On the other hand phenolic compounds and flavonoids act as free radical scavengers and antioxidants. Plant antioxidants are safer than synthetic antioxidants (Gurpreet et al., 2006). The antioxidant activity of the plant could be related to hydroxyl group due to their polar nature (Prasad et al., 2005). Various plant species have been tested for antioxidant activity using DPPH assay (Wong et al., 2006; Annan and Houghton, 2008; Dall'Acqua et al., 2008; Borneo et al., 2009; Rohman and Man, 2010) and maximum activity was exhibited by Rupus ulmifolius with an $\mathrm{IC}_{50}$ value of $5.1 \mu \mathrm{g} \mathrm{\textrm {mL } ^ { - 1 }}$ (Dall'Acqua et al., 2008) and the lowest activity were exhibited by Thelesperma megapotamicam with the $\mathrm{IC}_{50}$ value of $2000 \mu \mathrm{g} \mathrm{mL} \mathrm{mL}^{-1}$ (Borneo et al., 2009).
Antioxidant activity of the leaves of Calophyllum rubiginosum exhibited antioxidant activity with an $\mathrm{IC}_{50}$ value of $0.11 \mathrm{mg} \mathrm{mL}^{-1}, 0.23$ and $4.5 \mathrm{mg} \mathrm{mL}^{-1}$ for DCM, Methanol and hexane extracts (Taher et al., 2010).

Plants and the plant constituents have received much attention in the treatment of diabetes, as researchers have identified hypoglycaemic agents from medicinal plants (Youn et al., 2004). Plant extracts containing $\alpha$-amylase and $\alpha$-glucosidase inhibitors have been reported (Shirwaikar et al., 2005) but not been identified in Araucaria cookii, Bauhinia blakeana and Brassaia actinophylla. Flavonoids and polyphenols are natural antidiabetic agents (Andrade-Cetto et al., 2008). Plant phytochemicals has inhibitory activities against enzymes responsible for carbohydrate hydrolysis and subsequently lowers postprandial hyperglycemia and helpsin the management of diabetes which was observed in vivo (Mai et al., 2007). Hemolytic activity of these extracts was checked with human erythrocytes. The $\mathrm{IC}_{50}$ values for all the extracts for hemolytic activity are less than $200 \mu \mathrm{g} \mathrm{mL}^{-1}$. From the results it is clear that none of the plant ext racts possessed hemolytic activity against human erythrocytes.

\section{CONCLUSION}

The findings of our study show that the three plants extract has antioxidant, antimicrobial and enzyme inhibitory potential, due to the presence of various phytochemicals in the plant extracts. The phytochemical and pharmacological evaluation of the plant extracts states that these three ornamental plants possess medicinally important metabolites. Further Studies on the bioactive compounds of these plants in vivo should be carried out for the development of new compounds for the treatment of diabetes. Hemolysis at a concentration of $200 \mu \mathrm{g} \mathrm{mL}^{-1}$ is considered to be active.

\section{ACKNOWLEDGEMENT}

We thank the management of VIT University for providing necessary facilities to carry out our research work. 


\section{REFERENCES}

Agrawal, P., V. Rai and R.B. Singh, 1996. Randomized, placebo-controlled, single blind trial of holy basil leaves in patients with noninsulin-dependent diabetes mellitus. Int. J. Clin. Pharmacol. Ther., 34: 406-409. PMID: 8880292

Akiyama, H., F. Kazuyasu, O. Yamasaki, T. Oono and T. Iwatsuki, 2001. Antibacterial action of several tannins against Staphylococcus aureus. J. Antimicrob. Chemother., 48: 487-491. DOI: 10.1093/jac/48.4.487

Ali, H., P.J. Houghton and A. Soumyanath, 2006. AlphaAmylase inhibitory activity of some Malaysian plants used to treat diabetes; with particular reference to Phyllanthus amarus. J. Ethnopharmacol., 107: 449-455. PMID: 16678367

Ames, B.N., L.S. Gold and W.C. Willet, 1995. The causes and prevention of cancer. Proc. Natl. Acad. Sci. USA., 92: 5258-5265. PMCID: PMC41674

Andrade-Cetto, A., J. Becerra-Jimenez and R. CardenasVázquez, 2008. Alfa-glucosidase-inhibiting activity of some Mexican plants used in the treatment of type 2 diabetes. J. Ethnopharmacol., 116: 27-32. PMID: 18082348

Annan, K. and P.J. Houghton, 2008. Antibacterial, antioxidant and fibroblast growth stimulation of aqueous extracts of Ficus asperifolia Miq. and Gossypium arboreum L., wound-healing plants of Ghana. J. Ethnopharmacol., 119: 141-144. DOI: 10.1016/j.jep.2008.06.017

Borneo, R., A.E. Leon, A. Aguirre, P. Ribotta and J.J. Cantero, 2009. Antioxidant capacity of medicinal plants from the Province of Córdoba (Argentina) and their in vitro testing in a model food system. Food Chem., 112: 664-670. DOI: 10.1016/j.foodchem.2008.06.027

Cerutti, P.A., 1994. Oxy-radicals and cancer. Lancet, 344: 862-863. DOI: 10.1016/S0140-6736(94)92832-0

Chitme, H. R., R. Chandra and S. Kaushik, 2004. Studies on anti-diarrhoeal activity of Calotropis gigantea R.Br. in experimental animals. J. Pharm. Pharm. Sci., 7: 70-75. PMID: 15144737

Cowan, M.M., 1999. Plant products as antimicrobial agents. Clin. Microbiol. Rev., 12: 564-582. PMID: 10515903

Dall'Acqua, A., K. Deckelnick and H.C. Grunau, 2008. Classical solutions to the Dirichlet problem for Willmore surfaces of revolution. Adv. Calculus Variat., 1: 379-397. DOI: 10.1515/ACV.2008.016
Dini, O., T. Schettino, T. Simioli and A. Dini, 2001. Studies on the constituents of Chenopodium quinoa seeds: Isolation and characterization of new triterpene saponins. J. Agric. Food Chem., 49: 741746. PMID: 11262022

Edeoga, H.O., D.E. Okwu and B.O. Mbaebie, 2005. Phytochemical constituents of some Nigerian medicinal plants. Afr. J. Biotechnol., 4: 685-688.

Evans, W.C., 1997. An index of medicinal plants. Textbook Pharmacognosy, 7: 12-14.

Finer, I.L., 1988. Organic Chemistry: Stereochemistry and the Chemistry of Natural Products. 5th Edn., Addison-Wesley Longman, Incorporated, Harlow, ISBN-10: 0582030676, pp: 942.

Gurpreet, K., A.M. Saqrwar, J. Zoobi, J. Kaleem and A. Mohemmad, 2006. Evaluation of antioxidant activity of Cassia siamea flowers. J. Ethanopharmacol., 108: 340-348. DOI: 10.1016/j.jep.2006.05.021

Halliwell, B. and J.M.C. Gutteridge, 1989. Free radicals in Biology and Medicine. 2nd Edn., Clarendon Press, Oxford, ISBN-10: 0198552912, pp: 543.

Hill, A.F., 1952. Economic Botany: A Textbook of Useful Plants and Plant Products. 2nd Edn., McGraw-Hill Book Company Inc., New York, pp: 560.

Ingrid, F. and F.M. Matthias, 2006. Traditionally used plants in diabetes therapy-phytotherapeutics as inhibitors of $\alpha$-amylase activity. Rev. Bras. Farmacogn., 16: 1-5. DOI: 10.1590/S0102695X2006000100002

Iqbal, K., F. Liu, C.X. Gong, A.D.C. Alonso and I. Grundke-Iqbal, 2009. Mechanisms of tau-induced neurodegeneration. Acta Neuropathol., 118: 53-69. DOI: $10.1007 / \mathrm{s} 00401-009-0486-3$

Kalemba, D. and A. Kunicka, 2003. Antibacterial and antifungal properties of essential oils. Curr. Med. Chem., 10: 813-829. PMID: 12678685

Kiselova, Y., D. Ivanova, T. Chervenkov, D. Gerova and B. Galunska et al., 2006. Correlation between the In Vitro antioxidant activity and polyphenol content of aqueous extracts from bulgarian herbs. Phytotherapy Res., 20: 961-965. DOI: 10.1002/ptr.1985

Kokate, C.K., 1999. Phytochemical Methods. Phytotherapy, 78: 126-129.

Mace, M.E., 1963. Histochemical localization of phenols in healthy and diseased banana roots. Physiol. Plantarum, 16: 915-925. DOI: 10.1111/j.13993054.1963.tb08367.x 
Mai, T.T., N.N. Thu, P.G. Tien and N. Van Chuyen, 2007. Alpha-glucosidase inhibitory and antioxidant activities of Vietnamese edible plants and their relationships with polyphenol contents. J. Nutr. Sci. Vitaminol., 53: 267-276. PMID: 17874833

McCue, P., Y.I. Kwon and K. Shetty, 2005. Anti-diabetic and anti-hypertensive potential of sprouted and solidstate bioprocessed soybean. Asia. Pac. J. Clin. Nutr., 14: 145-152. PMID: 15927931

Menser, L.I., F.S. Menezes, G.G. Leitao, A.S. Santos and T.C. Coube et al., 2001. Screening of Brazilian plant extracts for antioxidant activity by the use of DPPH free radical method. Phytother. Res., 15: 127-130. PMID: 11268111

Nascimento, G.G.F., J. Lacatelli, P.C. Freitas and G.L. Silva, 2000. Antibacterial activity of plant extracts and phytochemicals on antibiotic-resistant bacteria. Braz. J. Microbiol., 31: 886-891. DOI: 10.1590/S1517-83822000000400003

Osbourn, A.E., 2003. Saponins in cereals. Phytochemistry, 62: 1-4. DOI: 10.1016/S00319422(02)00393-X

Owolabi, J. and E.K.I. Omogbai, 2007. Analgesic and anti inflammatory activities of ethanolic sstem bark extract extract of Kigelia africana (Bignoniace). Afr. J. Biotech., 6: 582-585.

Pietta, P.G., 2000. Flavonoids as antioxidants. J. Nat. Prod., 63: 1035-1042. PMID: 10924197

Prasad, N.K., S. Divakar, G.R. Shivamurthy and S.M. Aradhya, 2005. solation of a free radical-scavenging antioxidant from water spinach (Ipomoea aquatica Forsk). J. Sci. Food Agric., 85: 1461-1468. DOI: $10.1002 /$ jsfa. 2125
Rohman, A. and Y.B.C. Man, 2010. Fourier transform infrared (FTIR) spectroscopy for analysis of extra virgin olive oil adulterated with palm oil. Food Res. Int., 43: 886-892. DOI: 10.1016/j.foodres.2009.12.006

Shirwaikar, A., K. Rajendran and I.S.R. Punitha, 2005. Antidiabetic activity of alcoholic stem extract of Coscinium fenestratum in streptozotocinnicotinamide induced type 2 diabetic rats. J. Ethnopharmacol., 97: 369-374. PMID: 15707777

Taher, M., N. Attoumani, D. Susanti, S.J.A. Ichwan and F. Ahmed, 2010. Antioxidant activity of leaves of Calophyllum rubiginosum. Am. J. Applied Sci., 7: 1305-1309. DOI: 10.3844/ajassp.2010.1305.1309

Trease, G.E. and W.C. Evans, 1996. A Textbook of Pharmacognosy.14th Edn., Bailliere Tindall Ltd, London, ISBN-10: 9780702018992, pp: 612.

Wong, O.I., E.V. Ryan-Weber, D.A. Garcia-Appadoo, R.L. Webster and L. Staveley-Smith et al., 2006. The Northern HIPASS catalogue-data presentation, completeness and reliability measures. Monthly Notices Royal Astronomical Soc., 371: 1855-1864. DOI: 10.1111/j.1365-2966.2006.10846.x

Youn, J.Y., H.Y. Park and K.H. Cho, 2004. Antihyperglycemic activity of Commelina communis L.: inhibition of alpha-glucosidase. Diabetes Res. Clin. Pract., 66: S149-S155. PMID: 15563967 